\title{
The Local Control of the Pituitary by Activin Signaling and Modulation
}

\author{
Louise M. Bilezikjian* and Wylie W. Vale
}

Clayton Foundation Laboratories for Peptide Biology, Salk Institute for Biological Studies, La Jolla, California, USA

\begin{abstract}
The pituitary gland plays a prominent role in the control of many physiological processes. This control is achieved through the actions and interactions of hormones and growth factors that are produced and secreted by the endocrine cell types and the non-endocrine constituents that collectively and functionally define this complex organ. The five endocrine cell types of the anterior lobe of the pituitary, somatotropes, lactotropes, corticotropes, thyrotropes and gonadotropes, are defined by their primary product, growth hormone (GH), prolactin (PRL), adrenocorticotropic hormone (ACTH), thyroid-stimulating hormone (TSH) and follicle stimulating hormone (FSH)/luteinizing hormone (LH). They are further distinguishable by the presence of cell surface receptors that display high affinity and selectivity for specific hypothalamic hormones and couple to appropriate downstream signaling pathways involved in the control of cell type specific responses, including the release and/or synthesis of pituitary hormones. Central control of the pituitary via the hypothalamus is further fine-tuned by the positive or negative actions of peripheral feedback signals and of a variety of factors that originate from sources within the pituitary. The focus of this review is the latter category of intrinsic factors that exert local control. Special emphasis is given to the TGF- $\beta$ family of growth factors, in particular activin effects on the gonadotrope population, because a considerable body of evidence supports their contribution to the local modulation of the embryonic and postnatal pituitary as well as pituitary pathogenesis. A number of other substances, including members of the cytokine and FGF families, VEGF, IGF1, PACAP, Ghrelin, adenosine and nitric oxide have also been shown or implicated to function as autocrine/paracrine factors, though, definitive proof remains lacking in some cases. The ever-growing list of putative autocrine/paracrine factors of the pituitary nevertheless has highlighted the complexity of the local network and its impact on pituitary functions.
\end{abstract}

Keywords: Pituitary, gonadotrope, FSHbeta, LHbeta, gonadotropin, activin, inhibin, follistatin, bone morphogenetic proteins, FOXL2, BPES, Smad.

\section{A BRIEF PERSPECTIVE OF THE PITUITARY AND TGF- $\beta$ LIGANDS}

The historical view of the pituitary as the 'master' endocrine gland derives from the broad spectrum of physiological and homeostatic processes that are controlled and/or influenced by the actions of hormones produced by this organ. Some of the prominent actions of anterior pituitary hormones include the anabolic and growthpromoting actions of growth hormone $(\mathrm{GH})$, the control of sexual maturation and fertility by the gonadotropins ( $\mathrm{LH}$ and FSH), adaptation and responses to stress and immune activation via ACTH, the effects of PRL on lactation and the critical role of TSH on thyroidogenesis and thyroid function [1]. Appropriate control of the endocrine pituitary cell types that specialize in producing these hormones is therefore critical for survival and general health. This control is achieved by the coordinated actions of central inputs, via the actions of hypothalamic peptide hormones including GHRH, somatostatin, GnRH, CRF, TRH as well as non-peptide inputs such as dopamine, and a variety of peripheral feedback signals [2]. The actions of these extrinsic control signals are further influenced by the immune system through

*Address correspondence to this author at the Clayton Foundation Laboratories for Peptide Biology, Salk Institute for Biological Studies, 10010 North Torrey Pines Rd, La Jolla, CA 92037, USA;

E-mail: Bilezikjian@salk.edu the direct or indirect actions of cytokines, and the variety of autocrine and/or paracrine factors that are produced locally by both the endocrine and non-endocrine cells of the pituitary [3]. Appropriate pituitary function might also be achieved through processes designed to replenish, expand or maintain population sizes [4-6]. A genetic lineage tracing strategy has identified a population of nestin-positive stemlike cells of the adult mouse pituitary capable of differentiating into all pituitary cell lineages [7]. Stem-like and sphere-forming cells of mouse and human pituitaries have been enriched and shown to express embryonic pituitary cell markers and retain proliferative potential [811]. The human pituitary has been shown to contain populations of cells that display stem/progenitor characteristics, retain neoplastic potential and express markers of self-renewal [12]. The extent to which these cells contribute to the maintenance of pituitary integrity and functionality in vivo has yet to be validated. More than likely, the regulation of the pituitary cell populations is achieved by the combinatorial information supplied by all of these mechanisms, context-dependent alterations in each population as well as a variety of genetic and epigenetic factors that dictate cellular behaviors.

This review highlights key features of the autocrine/paracrine control of the differentiated pituitary, with a primary focus on the actions of activin and its antagonists on gonadotropes. The function of these cells is critical for normal reproductive function as they are the 
source of $\mathrm{LH}$ and $\mathrm{FSH}$, which are heterodimers of the unique $\mathrm{LH} \beta$ and FSH $\beta$, respectively, and the $\alpha \mathrm{GSU}$ subunit shared by both. Members of the TGF- $\beta$ family play prominent and diverse roles in the control of many processes including cell growth, differentiation and apoptosis, proliferation and differentiation of embryonic stem cells, maintenance of homeostatic mechanisms, immune responses as well as tissue remodeling and repair [13-15]. Further validation for the importance of this family comes from observations showing associations between deregulated TGF- $\beta$ ligand signaling and diseases, cancers and cancer metastasis [16]. Research since the initial characterization of inhibin and activin as FSH-inhibiting and -releasing factors, respectively, has led to insight into their significance and identified the contribution of several other members of the TGF- $\beta$ family of ligands in the pituitary [17]. The TGF- $\beta$ ligands have important roles in the postnatal as well as the embryonic pituitary. Several members of this family exert cell type specific effects and are implicated as components of the autocrine/paracrine network of the adult anterior pituitary [17]. During pituitary organogenesis, opposing BMP-4 and BMP-2 gradients are critical for survival and proliferation of the pituitary progenitors and for dorsal-ventral patterning of the mouse pituitary pouch $[18,19]$. Such signals might also be critical for the maintenance of the progenitor/stem cell niche of the postnatal pituitary, as they are in other tissues [14]. Growing evidence further implicates the intra-pituitary activin/follistatin network as a critical checkpoint for pathogenic mechanisms that lead to pituitary cell proliferation and tumor formation [20-22].

Inhibins were first characterized as gonadal feedback modulators with inhibitory effects on FSH secretion from preparations of rodent pituitary cells [23]. The analysis of side-fractions of the purified inhibin preparations subsequently led to the identification of activins and the realization that activins and inhibins are members of the TGF- $\beta$ family and function antagonistically to stimulate and inhibit FSH secretion, respectively [23]. The existence of a non-steroidal feedback signal originating from the gonads had been anticipated from multiple in vivo and in vitro studies and the demonstration that charcoal-treated follicular fluid suppressed the secondary FSH rise [23]. Similarly, the concept of the existence of an FSH-releasing factor, other than hypothalamic GnRH, was developed based upon many observations including the ovariectomy-induced rapid initial rise in circulating FSH without an accompanied change in LH [23]. Inhibin and activin fulfilled the criteria as FSHinhibiting and -stimulating factors, respectively [23].

Numerous studies utilizing genetically modified rodent models and also guided by phenotypic observations of pituitary anomalies in human patients have since validated these initial observations of activin and inhibin action and expanded the scope of their targets and actions [24-27]. These studies have also led to the realization that additional members of the TGF- $\beta$ family might also have cell type specific roles in the pituitary. Variable effects of BMPs on FSH secretion and FSH $\beta$ expression have been reported [2830]. Inhibitory effects of BMP-2/4 on the transcription of proopiomelanocortin (POMC) in corticotropic AtT20 cells seems to be mediated through interference with Pitx and/or Tpit and involve ALK3/6 type I receptors [31]. The extent to which member of the bone morphogenetic protein (BMP) family play a significant role in the postnatal pituitary still remains an open question but they are implicated in pituitary tumorigenesis [32]. The presence of transcripts for BMP receptors and several BMP forms, including BMP-6, -7 and 15 in the mouse [33] and GDF9 in the human pituitary [34], is consistent with the possibility that they act locally. TGF$\beta 1$ and $-\beta 3$ are expressed in the pituitary and act through type II and type I TGF- $\beta$ receptors expressed on lactotropes to regulate PRL expression and the growth of this population [35]. Studies on rat anterior pituitary cells have shown that whereas TGF- $\beta 1$ from lactotropes works in an autocrine manner to suppress PRL expression, TGF- $\beta 3$ mediates the mitogenic actions of estrogen on lactotropes through a paracrine action mediated by basic fibroblast growth factor released from folliculostellate cells [36]. Recent data suggest that lactotropes are also targets of BMP-4 and activin [37]. Studies have further suggested that the Smad-menin association downstream of activin signaling participates in the control of normal cell growth and prevention of tumor cell growth [38].

\section{SIGNALING MECHANISMS USED BY THE TGF- $\beta$ FAMILY OF LIGANDS}

Ligands of the TGF- $\beta$ family signal through two types of transmembrane receptor serine/threonine kinases (RSK), type I (collectively referred to as ALKs, activin receptor-like kinases) and type II receptors [13]. Downstream signaling is initiated upon ligand binding to both receptors and the formation of an active heteromeric complex, several of which have been validated by recent crystallographic studies [39-41]. An added complexity is generated by the ability of each ligand to interact with more than one receptor and, conversely, of each receptor type to display sufficiently high affinity for more than one ligand, at least under appropriate circumstances [13]. Ligand-receptor choices are ultimately dictated the availability of a particular receptor type at a given site in addition to the structural features that permit the formation of high affinity ligand-receptor complexes. In the case of TGF- $\beta$ isoforms or activins, high-affinity ligand binding to the respective type II receptor is a critical event that establishes the interface for type I receptor binding, explaining the low or negligible affinity of either ligand for type I receptors [13]. By contrast, BMPs seem to interact with their respective type I and type II receptors with comparable affinity and, for this ligand subfamily, the type I receptor seems to make the major contribution for high affinity binding [13, 42].

Activins transmit their signals through two of the five mammalian type II receptors known to exist, ActRII and ActRIIB, and one of seven type I receptors, ActRIB/ALK4 [13]. ALK4 is the primary type I receptor used by dimeric activins but recent evidence suggests that activin B also signals through ALK7 [43]. The T $\beta$ RII and T $\beta$ RI/ALK5 combination is the primary pair used by TGF- $\beta$ isoforms although recent evidence suggests that TGF- $\beta$ engages and signals through other type I receptors under certain circumstances [44, 45]. The BMP and GDF subset of the TGF- $\beta$ family, on the other hand, can signal through ActRIIA, ActRIIB or BMPRII in combination with BMPRIA/ALK3 or BMPRIB/ALK6 but also through additional type I receptors [42, 46]. 
The cytoplasmic domains of both type I and type II receptors possess serine/threonine kinase activity and also serve as docking stations [46]. According to the currently accepted model for receptor activation, the formation of the heteromeric ligand-receptor complex brings the cytoplasmic domains of the two receptor types into close proximity to each other, thereby allowing the constitutively active type II receptor to phosphorylate key residues within a glycine- and serine-rich (GS) domain of the type I receptors [46, 47]. The phosphorylated type I receptors are then able to transiently recruit and phosphorylate a class of signaling proteins known as Smads [46]. The Smad pathway is considered to be the major but not the only mode of signaling by the TGF- $\beta$ family of ligands [48]. Moreover, there is considerable crosstalk between Smad and non-Smad pathways [48]. The Smad family can be generally grouped into subcategories based upon whether they are receptor-activated (pathwayrestricted, R-Smads) or not (common mediator, co-Smad), whether they serve a modulatory role (inhibitory, I-Smads) and by the identity of the ligands that induce their phosphorylation [46]. Activins and TGF- $\beta$ isoforms signal primarily via Smad2 and/or Smad3 [48]. BMP signaling, on the other hand, occurs through activation of Smad1, 5 and/or $8[42,46]$. Smad1 and Smad5 might also transmit TGF- $\beta$ signals in some situations $[42,46]$. The promiscuous Smad4 is shared by all Smads and is the only known co-Smad of the human genome [49]. Two vertebrate inhibitory Smads, Smad6 and Smad7 are inducible targets of the Smad pathway [46]. They provide a negative feedback signal for pathway regulation by transiently binding to the cytoplasmic domains of the type I receptors and preventing phosphorylation and activation of pathway-specific Smads [50-54].

Smads are structurally characterized as having an $\mathrm{N}$ terminal MH1 (Mothers against decapentaplegic homology domain 1) and a C-terminal $\mathrm{MH} 2$ domain connected by a linker region [55-58]. The MH1 domain mediates DNA binding and contains the nuclear localization signal [46]. The $\mathrm{MH} 2$ domain, on the other hand, supports transactivation when fused to the Gal4-DNA binding domain and incorporates a structural feature known as the L3 loop, which is critical for the specific association of R-Smads and ISmads to the L45 loop of type I receptors [59]. The L3 loop of the MH2 domain is also involved in homo- or heterooligomerization of Smads [60]. In the case of R-Smads, a conserved C-terminal SSXS motif, which is missing in ISmads and Smad4, is a substrate of the protein kinase activity that resides in the cytoplasmic tail of the type I receptor [55-58]. Phosphorylation of $\mathrm{S}^{*} \mathrm{XS}$ relieves an inhibitory conformation to allow the L3 loop to engage in homo- or hetero-oligomerization for subsequent shuttling into the nucleus in association with Smad4 [60]. Additional phosphorylation sites in the linker region serve as substrates of protein kinases activated by other signaling pathways including MAPK and mediate cross-talk of the pathways [61-65]. In the nucleus, recruitment of activated Smad complexes to regulatory elements brings about activation or inhibition of target gene transcription through association with coactivators or corepressors, respectively [46]. An important difference between Smad2 and Smad3 is that a short insert in the MH1 domain of Smad2 interferes with the DNA-binding function of this domain $[59,66]$. Thus, Smad 2 assembly at DNA target sites occurs via interacting partners such as Smad4 or FoxH1/FAST1/2 [67-69]. Most studies suggest that $\mathrm{Smad} 2$ and $\mathrm{Smad} 3$ are interchangeable and show that they display considerable functional overlap and combinatorial actions [70]. It is clear from targeted inactivation studies, however, that Smad2 and Smad3 indeed control distinct developmental and cellular processes [7074]. Smad functions are also subject to regulation by a variety of mechanisms that influence their stability, cellular distribution and phosphorylation status, discussions of which are beyond the scope of this review [75].

\section{PITUITARY ACTIONS OF ACTIVIN AND ANTAGO- NISM BY INHIBIN}

Activins (activin A or B) are assembled and secreted as disulfide-linked dimers of inhibin $\beta \mathrm{A}$ or $\beta \mathrm{B}$ subunits whereas inhibins are generated through heterodimeric association of the inhibin $\beta \mathrm{A}$ or $\beta \mathrm{B}$ subunits with the inhibin $\alpha$ subunit [23]. These TGF- $\beta$ family members were initially characterized by their actions to stimulate (activins) or inhibit (inhibins) FSH secretion from the pituitary [23, 7678]. The subunits, in particular $\beta A$ and $\beta B$, are expressed in a wide variety of tissues and the corresponding dimeric forms act locally to regulate relevant and diverse biological processes [79]. Inhibins, more so than activins, have additional roles as classical endocrine factors [23] and substantial evidence implicates them in tumor suppression $[80,81]$. In general, inhibins and activins are functional antagonists, but not all activin-responsive cell types display inhibin sensitivity consistent with the requirement for additional components. Several candidate proteins have been proposed to function as inhibin receptors or co-receptors [8285]. The quest for an inhibin receptor or co-receptor led to the identification of betaglycan (or T $\beta$ RIII) and the realization that this protein, previously characterized as a TGF- $\beta 2$ co-receptor, indeed has a dual function to promote the actions of both TGF- $\beta 2$ and inhibin [86].

The functional relevance of betaglycan in mediating inhibin antagonism is supported by a number of observations. Betaglycan is expressed in inhibin-responsive gonadotropes [87]. Betaglycan immunoreactivity at the membrane of gonadotropes and FSH levels show an inverse correlation in late estrus when inhibin levels are rising and establishing feedback control of FSH secretion [88]. When introduced into heterologous cells that otherwise do not display appreciable responses to inhibin, betaglycan expression at the cell surface is sufficient for high affinity ${ }^{125}$ I-inhibin binding and high potency antagonism of activin by inhibin [86]. On the other hand, RNAi-mediated knockdown of endogenous betaglycan in primary cultures of rat anterior pituitary cells or in the L $\beta \mathrm{T} 2$ gonadotropic cell line compromises the ability of inhibin to antagonize activinstimulated FSH secretion [89, 90]. Similarly, the inhibinbinding function of betaglycan is compromised in the presence of an immunoneutralizing antibody directed to an epitope of the extracellular domain of betaglycan that encompasses amino acid residues required for inhibin binding [89]. Whereas RNAi-mediated knockdown of betaglycan compromises its actions to promote TGF- $\beta 2$ signaling and to mediate inhibin antagonism, the antibody selectively disrupts inhibin antagonism because a more distal portion of the extracellular domain seems to be sufficient for 
high affinity TGF- $\beta 2$ binding and function $[89,91]$. A model of differential betaglycan-inhibin versus betaglycan-TGF- $\beta 2$ action has emerged. Inhibin or TGF- $\beta$ binding to betaglycan promotes high affinity interactions of these ligands with relevant type II receptors, ActRII, ActRIIB and BMPRII in the case of inhibin and T $\beta$ RII in the case of TGF- $\beta 2$, but leads to distinct outcomes for each ligand [91]. A ternary complex of betaglycan-TGF- $\beta 2$-T $\beta$ RII promotes TGF- $\beta 2$ binding to the type I TGF- $\beta$ receptor, ALK5, leading to increased cellular sensitivity to the ligand and activation of downstream Smad2/3 phosphorylation and signaling [92]. Inhibin binding to betaglycan also promotes high affinity binding of the ligand to type II receptors but in this case, the ternary complex of betaglycan-inhibin-type II receptor does not lead to type I receptor recruitment and, importantly, sequesters the type II receptors thereby preventing ligands such as activins or BMPs to assemble active ligand-receptor complexes and generate downstream signals [91, 93, 94]. The two functions of betaglycan are separable but competition between TGF- $\beta 2$ and inhibin binding has been shown to affect inhibin potency in L $\beta$ T2 cells [95]. Conversely, accelerated internalization of inhibin-bound betaglycan has been shown to antagonize TGF- $\beta 2$ action [96].

Given the duality and complexity of betaglycan function, it might not be too surprising that betaglycan expression in a particular cell type is not predictive of inhibin sensitivity, suggesting that, in some cell types and under certain circumstances, additional components contribute to or interfere with the function of betaglycan as an inhibin coreceptor [97]. Pituitary lactotropes, for example, express endogenous betaglycan and are responsive to TGF- $\beta$ but do not display measurable sensitivity to inhibin [87]. The mechanistic basis for this is not currently known but the observation is consistent with the notion that components other than betaglycan contribute to differential inhibin and TGF- $\beta 2$ sensitivity. Betaglycan mutant mice display cardiac and liver defects and die during embryonic development probably due to deregulated TGF- $\beta$ signaling [98]. As a result of the embryonic phenotype, this mouse model, while informative in as far as demonstrating the importance of betaglycan during embryonic development, has not been instructive in as far as delineating the in vivo function of betaglycan as a co-receptor for inhibin. Further evaluation of this question awaits the development of mouse models that permit targeted or even inducible deletion of betaglycan.

TGF- $\beta$ ligands and receptors are present in the pituitaries of a variety of species including those of rodent, human and non-human primates. Studies of rodent anterior pituitaries show that inhibin $\alpha$ and $\beta \mathrm{B}$ subunit expression is restricted largely to gonadotropes [99] whereas inhibin $\beta \mathrm{A}$ is detectable in folliculostellate cells [100]. Primary pituitary cultures secrete activin B and activin A [101, 102]. Due to the low abundance of the secreted dimers, however, it has been difficult to quantify the local concentrations of dimeric activin or inhibin. Indirect evidence for the importance of local activin B in the rodent anterior pituitary ultimately came from in vivo and in vitro experiments in which an immunoneutralizing monoclonal antibody to activin B was utilized to show suppression of tonic FSH secretion and FSH $\beta$ mRNA expression without affecting LH levels [103106]. As expected, the relevant type II receptors, ActRII and
ActRIIB, are also present in the pituitary [107, 108]. ActRII is present throughout the pituitary, whereas ActRIIB expression is more limited to a subset of cells that includes gonadotropes [108].

Gonadotropes are the best characterized pituitary targets of activin but effects of exogenous activin A on most other pituitary cell types have been reported [109-113]. The primary action of activin on gonadotropes is to differentially activate FSH $\beta$ transcription and stimulate FSH secretion, but activin effects on LH $\beta$ expression have been reported [114]. The actions of activin are critical for the secondary FSH rise during the estrous cycle [115]. A variety of genetic models have been generated to assess the role of activin signaling in the pituitary. Despite the complications arising due to compensatory mechanisms, especially those that alter gonadal feedback signals, or broader defects that occur due to disruption of normal development and/or function of the gonads, these genetic models have provided a great deal of information [116]. For example, the importance of ActRII was revealed by studies of $A c v r 2$ mutant mice. These mice survived into adulthood but Acvr2 loss of function led to female infertility, lower FSH levels, lower GnRH binding and compromised fertility of the males [117]. Genetic ablation of $I n h b b$ was found to cause developmental anomalies as well as reproductive deficiencies in females but an unexpected rise in FSH levels presumably reflecting compensatory changes [118]. The loss of Smad3 was correlated with a reduced $\mathrm{LH} \beta$ and $\mathrm{FSH} \beta$ transcription [114, 119]. While these studies did not provide clear-cut answers, they confirmed that the activin system is important for optimal gonadotrope function and for maintaining a functionally intact reproductive axis.

Much of the current understanding of the mechanism underlying the actions of activin on the FSH $\beta$ promoter comes from studies of L $\beta \mathrm{T} 2$ cells as they express the relevant receptors that mediate activin and GnRH effects and the repertoire of required transcription factors [120]. The effects of activin on the FSH $\beta$ promoter are mediated largely through the Smad pathway, primarily Smad3 and Smad4, although the contribution of Smad-independent mechanisms has been implicated [121, 122]. Activin and GnRH act synergistically to activate the FSH $\beta$ promoter in L $\beta$ T2 cells [123-125]. Indeed, synergism between activin and different patterns of hypothalamic GnRH pulses, in conjunction with peripheral feedback signals, are critical for promoting the differential pattern of LH and FSH secretion throughout the estrus cycle [126]. Activin seems to be pivotal for a variety of inputs that are known to influence FSH expression. Gonadal steroids, for example, can directly target the FSH $\beta$ promoter but also exert indirect effects on FSH expression by altering the local activin tone of the pituitary [127]. The mechanisms underlying gonadotrope-specific expression of key components including FSH $\beta, \alpha G S U, L H \beta$ as well as the $\mathrm{GnRH}$ receptor in response to activin, GnRH and a variety of other key regulators of this cell type have been the subject of numerous studies. Details of these mechanisms were recently summarized by two review articles and thus are not covered here [121, 122].

Activin stimulation of gonadotropes, in addition to initiating signals that are critical for FSH production, also generates feedback signals that either promote or terminate 
further action. Activin has been shown to induce furin expression in pituitary cells and secondarily promote further processing of the activin subunit precursors and thereby increase ligand availability [128]. Activin induction of follistatin expression in pituitary gonadotropes, on the other hand, bio-neutralizes activin locally and leads to diminished signaling [129]. An additional action of activin to induce Smad7 imposes breaks on further Smad2/3 signaling and leads to diminished activation of downstream targets of the pathway [130]. Although many aspects of activin action on gonadotropes have been elucidated thus far, the extent to which observations from rodent models and cell lines can be extrapolated to the human pituitary requires further effort. Human pituitary adenomas express inhibin and activin subunits and the relevant signaling receptors and comparisons of normal pituitary tissue to adenomas suggest that, unlike the pattern seen in rodent pituitaries, ActRII rather than ActRIIB might be more relevant in the human pituitary [131-133]. The inhibin $\beta \mathrm{B}$ subunit is expressed at higher levels in FSH-producing pituitary adenomas compared to non-functioning adenomas, suggesting that this subunit is associated with gonadotropes, as it is in the rodent pituitary [132]. Cultured neoplastic cells derived from human pituitary adenomas display responses to activin and are growth-inhibited in response to this ligand [20, 134]. Interestingly, neoplastic pituitary cells also display diminished follistatin mRNA expression, suggesting that an imbalance in the activin and follistatin ratio might be a contributing factor [20].

\section{ACTIONS AND MODULATION OF PITUITARY FOLLISTATIN}

Follistatins are cysteine-rich monomeric glycoproteins that bind and bioneutralize activin with high-affinity at a molar follistatin to activin ratio of $2: 1[135,136]$ but also bind and modulate the actions of myostatin and several BMPs [137-140]. Recent structural studies have provided insight into the basis of the bio-neutralizing action of follistatin [141-145]. The follistatin: activin crystal structure has suggested that antagonism is achieved because both type I and type II binding sites on activin are masked when two follistatin molecules are bound to dimeric activin [143]. Mutagenesis of type I binding residues on activin A, however, have little effect on the affinity of activin for follistatin whereas most but not all Alanine substitutions in the type II binding interface substantially affect follistatin binding to activin, indicating that follistatin and type II binding requirements on activin are not identical [145]. Follistatins were first identified as FSH-suppressing gonadal factors but are now appreciated to have broad significance in embryonic and adult tissues [140, 146, 147]. Follistatin and its ligands are often co-expressed [140, 148, 149] and many of the demonstrated actions of follistatins are presumed to reflect their local autocrine/paracrine bioneutralizing actions. Deregulation of follistatin function is associated with a variety of cancers, including pituitary adenomas [20] and has been implicated in tumor metastasis [150, 151]. Genetic ablation of $F s t$ causes many embryonic defects, including skeletal and cutaneous abnormalities, and causes mortality shortly after birth [152]. Follistatin overexpression, on the other hand, is associated with varying degrees of infertility, suppression of FSH levels only in one transgenic line that displayed widespread transgene expression as well as morphological defects leading to early arrest of folliculogenesis but variable effects on testis size [153]. Whereas the role of follistatin in spermatogenesis still remains an open question [154], the importance of this antagonist for the maintenance of folliculogenesis has received further support from anomalies seen in mice with granulosa-specific inactivation of Fst [155].

A single follistatin gene encodes two alternatively spliced mRNAs from which the FST-315 and the C-terminally truncated FST-288 variants are generated [156, 157]. An additional FST-303 form is a proteolytic cleavage product of FST-315 [140]. In general, the shorter FST-288 form is presumed to act locally due to its higher affinity for cell surface proteoglycans while FST-315 is the predominant circulating form [158]. The differential significance of these spliced forms remains largely unresolved. Data from genetic mouse models engineered to express only one spliced form of follistatin, however, are strengthening the notion that different isoforms have distinct functions [159, 160]. One of these studies reported that FST-315 but not FST-288 overexpression rescued the embryonic lethality of the Fst null mice but the mice displayed anomalies including female infertility resulting from ovarian defects, suggesting that some or most of the functions of FST-288 and FST-315 are not interchangeable [160]. The other study reached the conclusion that whereas FST-288 is sufficient for full survival of mice into adulthood, it is not sufficient for full fertility [159]. Despite the different conclusions reached, the results of these two studies clearly highlight the physiological relevance of isoform-specific actions of follistatin.

Several lines of evidence from in vitro and in vivo studies support the contribution of intra-pituitary follistatin to the control of reproductive functions. Follistatin transcripts are present in most anterior pituitary cell types, including gonadotropes and folliculostellate cells [161, 162]. The protein has been purified from bovine folliculostellate cells [163], bovine pituitary homogenates [164], ovine anterior pituitary cells [165] and shown to be secreted by rat anterior pituitary and folliculostellate (FS/D1h) cells [100, 166]. Perturbation of the local availability of activin in the presence of a follistatin-specific antiserum alters the potency of exogenous activin A to stimulate FSH secretion from cultured rat anterior pituitary cells [166]. A mutant form of activin A (K102E-activin A) that fails to bind to cell surface activin receptors but retains follistatin binding elevates basal FSH secretion by displacing activin from follistatin thereby increasing its local availability [141]. Antisense-mediated knockdown of endogenous follistatin leads to an increase in FSH $\beta$ mRNA [167]. Pituitary follistatin mRNA levels show dynamic fluctuations during the estrous cycle in a manner generally consistent with its role in modulating $\mathrm{FSH}$ production $[168,169]$ although the results of one study led to a different conclusion and suggested that the action of follistatin is to facilitate rather than suppress FSH production [170]. Pituitary follistatin levels are modulated in vitro by exogenous inhibin and by the feedback action of ovarian inhibin in vivo [171]. Gonadectomy elevates pituitary follistatin mRNA levels in both male and female rats, probably reflecting the loss of inhibin feedback from the gonads but also resulting from increased $\mathrm{GnRH}$ secretion 
$[172,173]$. The modulation of pituitary follistatin expression and changes in the intra-pituitary activin/follistatin balance has been proposed to, in part, indirectly mediate the actions of steroids on gonadotropin expression [174, 175]. Follistatin mRNA levels in the rodent pituitary are correlated with GnRH pulse frequency with rapid frequencies supporting maximal follistatin but no change in FSH $\beta$ mRNA and slower frequencies causing a selective rise in $\mathrm{FSH} \beta$ but no change in follistatin mRNA [176].

\section{GONADOTROPE-SPECIFIC ACTIVATION OF FOL- LISTATIN BY ACTIVIN}

Gonadotropes and folliculostellate cells are the primary sources of follistatin in the pituitary [99, 100]. Activin and $\mathrm{GnRH}$ exert direct effects on follistatin expression in gonadotropes and thereby activate an autocrine feedback loop that terminates further activin action [177, 178]. Folliculostellate cell-derived follistatin, on the other hand, exerts paracrine control of activin action on gonadotropes [179-181]. Activin is a potent inducer of follistatin mRNA expression in preparations of primary rat anterior pituitary cells [182]. This action of activin is antagonized by inhibin co-treatment, suggesting that gonadotropes are the primary source of activin-induced follistatin expression [182]. Consistent with this conclusion, Fst transcription is induced by activin treatment of $\alpha \mathrm{T} 3-1$ and L $\beta \mathrm{T} 2$ cells, two gonadotrope-derived cell lines [183]. Furthermore and contrary to expectations, activin has no effect on follistatin expression or secretion from pituitary folliculostellate cells despite their sensitivity to other actions of activin [100]. Folliculostellate cells, however, respond to pro-inflammatory cytokines such as interleukin-1 $\beta$ with a substantial increase in follistatin production [100]. These observations have led to the identification of a novel mechanism for gonadotropespecific induction of $F s t$ in response to activin signaling. The promoters of the rat or human FST genes have been evaluated in a variety of cell lines and shown to be targets of inputs such as the cAMP/TPA pathway in P19 and F9 embryonic carcinoma cells $[184,185]$, the $W n t / \beta$-catenin pathway in NCCIT human embryonic carcinoma and F9 teratocarcinoma cells $[186,187]$ and by PPAR $\alpha$ and PPAR $\gamma$ nuclear receptors in L $\beta$ T2 cells [188]. GnRH activates the Fst promoter in L $\beta$ T2 cells [189-191]. In non-pituitary cells such as HepG2 or HEK293T cells, the Fst promoter is induced by activin or TGF- $\beta$ via Smad2/3 [192, 193]. Unexpectedly, the same promoter fragments are unresponsive to activin in $\alpha \mathrm{T} 3-1$ or L $\beta \mathrm{T} 2$ gonadotrope cells $[183,192]$. The basis for this observation was resolved by the discovery that a Smad-binding element (SBE1) located in the first intron is required for activin-dependent induction of the Fst transcription in $\alpha \mathrm{T} 3-1$ and L $\beta$ T2 cells [183]. Smad3 but not Smad2 recruitment to SBE1 activates Fst transcription in response to activin [183]. Whereas SBE1 is absolutely required for activin/Smad3-dependent induction of Fst transcription in $\alpha \mathrm{T} 3-1$ or L $\beta \mathrm{T} 2$ cells, it does not mediate activin effects in non-gonadotrope pituitary cells including FS/D1h and TtT/GF folliculostellate cells (unpublished observations). In non-pituitary cells, such as HepG2 or HEK293T, upstream regulatory elements mediate Smad2/3 effects on Fst transcription and SBE1 is dispensable [193-195].
The basis for gonadotrope-specific activation of the Fst gene via SBE1 was resolved through an unbiased proteomic screen for Smad3 partners. These efforts led to the identification of Forkhead box L2 (FoxL2), a forkhead transcription factor and an obligatory partner of Smad3 for SBE1-dependent activation of $F s t$ transcription [193]. FoxL2 and Smad3 bind to two adjacent elements (FKHB and SBE1, respectively) located in the first intron of the Fst [193]. FoxL2 is permissive for Smad3-dependent activation of transcription and disruption of either element compromises activin-dependent activation of $F s t$ in $\alpha \mathrm{T} 3-1$ or L $\beta \mathrm{T} 2$ cells [193]. RNAi-mediated knockdown of endogenous FoxL2 in $\alpha$ T3-1 or L $\beta$ T2 (unpublished observations) cells attenuates activin/Smad3-dependent induction of Fst transcription [193]. Smad3 binding to the SBE1 site is induced upon initiation of activin signaling whereas FoxL2 recruitment to FKHB is less responsive to activin treatment and a portion of cellular FoxL2 seems to be constitutively bound to FKHB [193]. As in the case of Smad2 and its obligatory partnership with FoxH1 for high affinity binding to cognate DNA sequences on certain target genes, it is likely that FoxL2 bound to the FKHB site stabilizes Smad3 binding to the SBE1 site and thereby promotes Smad3-dependent activation of the Fst in cells such as $\alpha \mathrm{T} 3-1$ or L $\beta \mathrm{T} 2$ that express endogenous FoxL2 [193]. These observations raise the possibility that similar mechanisms of Smad2/3 partnerships with other forkhead proteins are also required for the modulation of follistatin expression in other cell types.

Interestingly, Foxl2 (also designated P-FrK) is expressed during early stages of pituitary development in the embryo [196, 197]. Expression persists into adulthood, largely confined to $\alpha G S U$-expressing gonadotropes and thyrotropes of the adult pituitary [193, 198]. This pattern suggests that FoxL2 plays a role during pituitary development as well as in differentiated gonadotropes and thyrotropes. FoxL2 actions in the developing pituitary are not known and a limited number of studies have only now begun to provide information about its relevance in the adult gonadotrope. Gnrhr transcription in $\alpha \mathrm{T} 3-1$ cells is regulated through the functional interactions of FoxL2 with Smads and Ap-1 via a composite regulatory element [199]. Consistent with its pattern of FoxL2 expression in the adult pituitary, Cga was shown to be a target in both gonadotrope- and thyrotropederived cell lines [198]. FoxL2 is required for Smad3dependent induction of Fst in $\alpha$ T3-1 and L $\beta$ T2 cells [193]. Recently, FoxL2 was shown to also mediate Smad3dependent induction of $F$ shb in L $\beta$ T2 cells [200, 201]. Collectively, these data point to the possibility that, by modulating the expression of key targets of gonadotropes, FoxL2 plays an important role in the pituitary to regulate the reproductive axis. These findings have opened a new avenue of exploration of FoxL2 significance beyond its wellestablished role in the ovary [202-204].

The forkhead family is represented by a large number of transcription factors that exert diverse effects and participate in many morphogenetic and homeostatic processes [205, 206]. A highly conserved DNA-binding domain with a characteristic helix-turn-helix core motif defines this family, hence the "winged-helix" designation. FoxL2 is a divergent and evolutionarily conserved member of the family [207, 208]. Mutations in FOXL2 are associated with a condition known as Blepherophimosis-Ptosis-Epicanthus Inversus 
syndrome (BPES), with affected patients displaying eyelid defects and premature ovarian failure (POF) in female patients only with type I but not type II BPES [207, 209, 210]. FoxL2 is required for ovarian follicle formation and ablation of the gene disrupts granulosa cell differentiation, abnormal oocyte growth and infertility only in females [202, 203]. In the ovary, the transcriptional effects of FoxL2 on targets such as Cyp19 [211, 212] and StAR [213] indicate a regulatory role in steroidogenesis. Inducible deletion of Foxl2 in the adult ovary is sufficient to induce testicular markers in ovarian cells and reprogram them to testicular lineages, consistent with the requirement for FoxL2 to actively maintain ovarian follicles and prevent ovary to testis sex reversal [204]. The association of a missense mutation in FOXL2 with adult type granulosa cell tumors has further implicated a role for this factor as a tumor suppressor [214]. Clearly, FOXL2 has well defined functions in the ovary. Further studies on the pituitary are needed to assess the importance of FoxL2 function in the pituitary. Recent studies of the pituitaries obtained from Foxl2 mutant mice, however, are yielding compelling data. These experiments indicate that while loss of Foxl2 does not alter the relative number of $\alpha \mathrm{GSU} / \mathrm{LH} \beta$-positive gonadotropes, it leads to a selective decrease in the number of gonadotropes that express $\mathrm{FSH} \beta$ immunoreactivity ([215], manuscript in preparation).

\section{SUMMARY}

In summary, activin and its two antagonists, follistatin and inhibin, play crucial roles in the anterior pituitary to promote differential FSH production and thereby exert indirect control on folliculogenesis and fertility. Counterregulatory mechanisms that keep activin in check might also be critical for preventing pathological conditions that give rise to tumors. Activin signaling in gonadotropes is subject to at least two such counter-regulatory mechanisms, including betaglycan-mediated inhibin antagonism of activin signaling and Smad3/FoxL2-mediated induction of Fst. A better understanding of the mechanisms and relative importance of these complex processes will not be trivial and would be facilitated through the development of novel tools, such as cell-type specific, inducible models that allow dynamic deletion or overexpression of key components that modulate them.

\section{CONFLICT OF STATEMENT}

LMB has nothing to report. WV is a co-founder, consultant, equity holder, member of the Board of Directors and Scientific Advisory Board of Acceleron Pharma, Inc. In accordance with Salk Institute policy, WV derives patent and licensing income in the activin field.

\section{ACKNOWLEDGEMENTS}

The work described in this review article and LMB is supported in part by grant number 2R01HD046941 awarded by the National Institute of Child Health and Human Development. The content is solely the responsibility of the authors and does not necessarily represent the official views of the National Institute of Child Health and Human Development or the National Institutes of Health. The work is supported in part by the Clayton Medical Research Foundation, Inc. WV is a Clayton Medical Research
Foundation, Inc. Senior Investigator and is the Helen McLoraine Professor of Molecular Neurobiology.

\section{REFERENCES}

[1] Kaplan SA. The pituitary gland: a brief history. Pituitary 2007; 10(4): $323-5$

[2] Charlton H. Hypothalamic control of anterior pituitary function: a history. J Neuroendocrinol 2008; 20(6): 641-6.

[3] Denef C. Paracrinicity: the story of 30 years of cellular pituitary crosstalk. J Neuroendocrinol 2008; 20(1): 1-70.

[4] Seilicovich A. Cell life and death in the anterior pituitary gland: role of oestrogens. J Neuroendocrinol 2010; 22(7): 758-64.

[5] Nolan LA, Kavanagh E, Lightman SL, Levy A. Anterior pituitary cell population control: basal cell turnover and the effects of adrenalectomy and dexamethasone treatment. J Neuroendocrinol 1998; 10(3): 207-15.

[6] Vankelecom H, Gremeaux L. Stem cells in the pituitary gland: A burgeoning field. Gen Comp Endocrinol 2010; 166(3): 478-88.

[7] Gleiberman AS, Michurina T, Encinas JM, et al. Genetic approaches identify adult pituitary stem cells. Proc Natl Acad Sci USA 2008 29; 105(17): 6332-7.

[8] Garcia-Lavandeira M, Quereda V, Flores I, et al. A GRFa2/Prop1/stem (GPS) cell niche in the pituitary. PLoS One 2009; 4(3): e4815.

[9] Kita A, Imayoshi I, Hojo M, et al. Hes1 and Hes5 control the progenitor pool, intermediate lobe specification, and posterior lobe formation in the pituitary development. Mol Endocrinol 2007; 21(6): 1458-66.

[10] Fauquier T, Rizzoti K, Dattani M, Lovell-Badge R, Robinson IC SOX2-expressing progenitor cells generate all of the major cell types in the adult mouse pituitary gland. Proc Natl Acad Sci USA 2008 26; 105(8): 2907-12.

[11] Chen J, Gremeaux L, Fu Q, Liekens D, Van Laere S, Vankelecom H. Pituitary progenitor cells tracked down by side population dissection. Stem Cells 2009; 27(5): 1182-95.

[12] Horvath E, Coire CI, Kovacs K, Smyth HS. Folliculo-stellate cells of the human pituitary as adult stem cells: examples of their neoplastic potential. Ultrastruct Pathol 2010; 34(3): 133-9.

[13] Massague J, Weis-Garcia F. Serine/threonine kinase receptors: mediators of transforming growth factor beta family signals. Cancer Surv 1996; 27: 41-64.

[14] Wu MY, Hill CS. Tgf-beta superfamily signaling in embryonic development and homeostasis. Dev Cell 2009; 16(3): 329-43.

[15] Xia Y, Schneyer AL. The biology of activin: recent advances in structure, regulation and function. J Endocrinol 2009 ; 202(1): 112.

[16] Massague J. TGFbeta in Cancer. Cell 2008; 134(2): 215-30.

[17] Bilezikjian LM, Blount A, Donaldson C, Vale W. Pituitary actions of ligands of the transforming growth factor- $\beta$ family: activins and inhibin. Reproduction 2006; 132: 207-15.

[18] Davis SW, Castinetti F, Carvalho LR, et al. Molecular mechanisms of pituitary organogenesis: In search of novel regulatory genes. Mol Cell Endocrinol 2010; 323(1): 4-19.

[19] Zhu X, Wang J, Ju BG, Rosenfeld MG. Signaling and epigenetic regulation of pituitary development. Curr Opin Cell Biol 2007 Dec; 19(6): 605-11.

[20] Danila DC, Inder WJ, Zhang X, et al. Activin effects on neoplastic proliferation of human pituitary tumors. J Clin Endocrinol Metab 2000; 85(3): 1009-15.

[21] Ezzat S. The role of hormones, growth factors and their receptors in pituitary tumorigenesis. Brain Pathol 2001; 11(3): 356-70.

[22] Risbridger GP, Schmitt JF, Robertson DM. Activins and inhibins in endocrine and other tumors. Endocr Rev 2001; 22(6): 836-58.

[23] Vale W, Hsueh A, Rivier C, Yu J. The inhibin/activin family of growth factors. In: Sporn MA, Roberts AB, Eds. Peptide Growth Factors and Their Receptors, Handbook of Experimental Pharmacology. Heidelberg: Springer-Verlag 1990; pp. 211-48.

[24] Matzuk MM, Kumar TR, Shou W, et al. Transgenic models to study the roles of inhibins and activins in reproduction, oncogenesis, and development. Recent Prog Horm Res 1996; 51: 123-54; discussion 55-7.

[25] Paez-Pereda M, Giacomini D, Refojo D, et al. Involvement of bone morphogenetic protein 4 (BMP-4) in pituitary prolactinoma pathogenesis through a Smad/estrogen receptor crosstalk. Proc Natl Acad Sci USA 2003; 100(3): 1034-9. 
[26] Alexander JM, Swearingen B, Tindall GT, Klibanski A. Human pituitary adenomas express endogenous inhibin subunit and follistatin messenger ribonucleic acids. J Clin Endocrinol Metab 1995; 80(1): 147-52.

[27] Haddad G, Penabad JL, Bashey HM, et al. Expression of activin/inhibin subunit messenger ribonucleic acids by gonadotroph adenomas. J Clin Endocrinol Metab 1994; 79(5): 1399-403.

[28] Huang HJ, Wu JC, Su P, Zhirnov O, Miller WL. A novel role for bone morphogenetic proteins in the synthesis of follicle-stimulating hormone. Endocrinology 2001; 142(6): 2275-83.

[29] Faure MO, Nicol L, Fabre S, et al. BMP-4 inhibits folliclestimulating hormone secretion in ewe pituitary. J Endocrinol 2005; 186(1): 109-21.

[30] Ho CC, Bernard DJ. Bone morphogenetic protein 2 signals via BMPR1A to regulate murine follicle-stimulating hormone beta subunit transcription. Biol Reprod 2009; 81(1): 133-41.

[31] Nudi M, Ouimette JF, Drouin J. Bone morphogenic protein (Smad)-mediated repression of proopiomelanocortin transcription by interference with Pitx/Tpit activity. Mol Endocrinol 2005; 19(5): 1329-42.

[32] Labeur M, Paez-Pereda M, Haedo M, Arzt E, Stalla GK. Pituitary tumors: cell type-specific roles for BMP-4. Mol Cell Endocrinol 2010; 326(1-2): 85-8.

[33] Otsuka F, Shimasaki S. A novel function of bone morphogenetic protein-15 in the pituitary: selective synthesis and secretion of FSH by gonadotropes. Endocrinology 2002; 143(12): 4938-41.

[34] Fitzpatrick SL, Sindoni DM, Shughrue PJ, Lane MV, Merchenthaler IJ, Frail DE. Expression of growth differentiation factor-9 messenger ribonucleic acid in ovarian and nonovarian rodent and human tissues. Endocrinology 1998; 139(5): 2571-8.

[35] Sarkar DK, Pastorcic M, De A, Engel M, Moses H, Ghasemzadeh MB. Role of transforming growth factor (TGF)-beta Type I and TGF-beta type II receptors in the TGF-beta1-regulated gene expression in pituitary prolactin-secreting lactotropes. Endocrinology 1998; 139(8): 3620-8.

[36] Hentges S, Boyadjieva N, Sarkar DK. Transforming growth factorbeta3 stimulates lactotrope cell growth by increasing basic fibroblast growth factor from folliculo-stellate cells. Endocrinology 2000; 141(3): 859-67.

[37] Giacomini D, Paez-Pereda M, Stalla J, Stalla GK, Arzt E. Molecular interaction of BMP-4, TGF-beta, and estrogens in lactotrophs: impact on the PRL promoter. Mol Endocrinol 2009; 23(7): 1102-14.

[38] Lebrun JJ. Activin, TGF-beta and menin in pituitary tumorigenesis. Adv Exp Med Biol 2009; 668: 69-78.

[39] Greenwald J, Vega M, Allendorph GP, Fischer W, Vale W, Choe S. A flexible activin can explain the membrane-dependent cooperative assembly of TGF-beta family receptors. Mol Cell 2004; 15(3): 485-9.

[40] Thompson TB, Woodruff TK, Jardetzky TS. Structures of an ActRIIB: activin A complex reveal a novel binding mode for TGFbeta ligand: receptor interactions. EMBO J 2003; 22(7): 1555-66.

[41] Allendorph GP, Vale WW, Choe S. Structure of the ternary signaling complex of a TGF-beta superfamily member. Proc Natl Acad Sci USA 2006; 103(20): 7643-8.

[42] Miyazono K, Kamiya Y, Morikawa M. Bone morphogenetic protein receptors and signal transduction. J Biochem 2010; 147(1): 35-51.

[43] Tsuchida K, Nakatani M, Yamakawa N, Hashimoto O, Hasegawa $\mathrm{Y}$, Sugino H. Activin isoforms signal through type I receptor serine/threonine kinase ALK7. Mol Cell Endocrinol 2004; 220(12): 59-65.

[44] Goumans MJ, Valdimarsdottir G, Itoh S, Rosendahl A, Sideras P, ten Dijke P. Balancing the activation state of the endothelium via two distinct TGF-beta type I receptors. EMBO J 2002; 21(7): 174353.

[45] Oh SP, Seki T, Goss KA, et al. Activin receptor-like kinase 1 modulates transforming growth factor-beta 1 signaling in the regulation of angiogenesis. Proc Natl Acad Sci USA 2000 Mar 14; 97(6): 2626-31.

[46] Massague J, Gomis RR. The logic of TGFbeta signaling. FEBS Lett 2006; 580(12): 2811-20.

[47] Schmierer B, Hill CS. TGFbeta-SMAD signal transduction: molecular specificity and functional flexibility. Nat Rev Mol Cell Biol 2007 Nov 14.
[48] Moustakas A, Heldin $\mathrm{CH}$. The regulation of TGFbeta signal transduction. Development 2009; 136(22): 3699-714.

[49] Hahn SA, Schutte M, Hoque AT, et al. DPC4, a candidate tumor suppressor gene at human chromosome 18q21.1. Science 1996; 271(5247): 350-3.

[50] Bai S, Cao X. A nuclear antagonistic mechanism of inhibitory Smads in transforming growth factor-beta signaling. J Biol Chem 2002; 277(6): 4176-82.

[51] Hayashi H, Abdollah S, Qiu Y, et al. The MAD-related protein Smad7 associates with the TGFbeta receptor and functions as an antagonist of TGF $\beta$ signaling. Cell 1997; 89(7): 1165-73.

[52] Nakao A, Afrakhte M, Moren A, et al. Identification of Smad7, a TGFbeta-inducible antagonist of TGF-beta signalling. Nature 1997; 389(6651): 631-5.

[53] Imamura $\mathrm{T}$, Takase $\mathrm{M}$, Nishihara $\mathrm{A}$, et al. Smad6 inhibits signalling by the TGF-beta superfamily. Nature 1997; 389(6651): 622-6.

[54] Lebrun J-J, Takabe K, Chen Y, Vale WW. Roles of pathwayspecific and inhibitory Smads in activin receptor signaling. Mol Endocrinol 1999; 13(1): 15-23.

[55] Massague J, Seoane J, Wotton D. Smad transcription factors. Genes Dev 2005; 19(23): 2783-810.

[56] Derynck R, Zhang Y, Feng XH. Smads: transcriptional activators of TGF-beta responses. Cell 1998; 95(6): 737-40.

[57] Attisano L, Wrana JL. Smads as transcriptional co-modulators. Curr Opin Cell Biol 2000; 12(2): 235-43.

[58] ten Dijke P, Miyazono K, Heldin CH. Signaling inputs converge on nuclear effectors in TGF-beta signaling. Trends Biochem Sci 2000; 25(2): 64-70.

[59] Lo RS, Chen YG, Shi Y, Pavletich NP, Massague J. The L3 loop: a structural motif determining specific interactions between SMAD proteins and TGF-beta receptors. EMBO J 1998; 17(4): 996-1005.

[60] Chacko BM, Qin B, Correia JJ, Lam SS, de Caestecker MP, Lin K. The L3 loop and C-terminal phosphorylation jointly define Smad protein trimerization. Nat Struct Biol 2001; 8(3): 248-53.

[61] Matsuura I, Wang G, He D, Liu F. Identification and characterization of ERK MAP kinase phosphorylation sites in Smad3. Biochemistry 2005; 44(37): 12546-53.

[62] Kretzschmar M, Doody J, Timokhina I, Massague J. A mechanism of repression of TGFbeta/ Smad signaling by oncogenic Ras. Genes Dev 1999; 13(7): 804-16.

[63] Kamaraju AK, Roberts AB. Role of Rho/ROCK and p38 MAP kinase pathways in transforming growth factor-beta-mediated Smad-dependent growth inhibition of human breast carcinoma cells in vivo. J Biol Chem 2005; 280(2): 1024-36.

[64] Matsuura I, Denissova NG, Wang G, He D, Long J, Liu F. Cyclindependent kinases regulate the antiproliferative function of Smads. Nature 2004; 430(6996): 226-31.

[65] Li P, Wang D, Lucas J, et al. Atrial natriuretic peptide inhibits transforming growth factor beta-induced Smad signaling and myofibroblast transformation in mouse cardiac fibroblasts. Circ Res. 2008; 102(2): 185-92.

[66] Shi Y, Wang YF, Jayaraman L, Yang H, Massague J, Pavletich NP. Crystal structure of a Smad MH1 domain bound to DNA: insights on DNA binding in TGF-beta signaling. Cell 1998; 94(5): 585-94.

[67] Chen X, Weisberg E, Fridmacher V, Watanabe M, Naco G, Whitman M. Smad4 and FAST-1 in the assembly of activinresponsive factor. Nature 1997; 389(6646): 85-9.

[68] Liu F, Pouponnot C, Massague J. Dual role of the Smad4/DPC4 tumor suppressor in TGF beta-inducible transcriptional complexes. Genes Dev 1997; 11(23): 3157-67.

[69] Zhou S, Zawel L, Lengauer C, Kinzler KW, Vogelstein B. Characterization of human FAST-1, a TGF beta and activin signal transducer. Mol Cell Biol 1998; 2(1): 121-7.

[70] Dunn NR, Vincent SD, Oxburgh L, Robertson EJ, Bikoff EK. Combinatorial activities of Smad2 and Smad3 regulate mesoderm formation and patterning in the mouse embryo. Development 2004; 131(8): 1717-28.

[71] Zhu Y, Richardson JA, Parada LF, Graff JM. Smad3 mutant mice develop metastatic colorectal cancer. Cell 1998; 94(6): 703-14.

[72] Waldrip WR, Bikoff EK, Hoodless PA, Wrana JL, Robertson EJ. Smad2 signaling in extraembryonic tissues determines anteriorposterior polarity of the early mouse embryo. Cell 1998; 92(6): 797-808.

[73] Ohnishi H, Miyata T, Yasuda H, et al. Distinct roles of Smad2-, Smad3-, and ERK-dependent pathways in transforming growth 
factor-beta1 regulation of pancreatic stellate cellular functions. J Biol Chem 2004; 279(10): 8873-8.

[74] Brown KA, Pietenpol JA, Moses HL. A tale of two proteins: differential roles and regulation of Smad 2 and Smad3 in TGF-beta signaling. J Cell Biochem 2007; 101(1): 9-33.

[75] Kang JS, Liu C, Derynck R. New regulatory mechanisms of TGFbeta receptor function. Trends Cell Biol 2009; 19(8): 385-94.

[76] De Kretser DM, Robertson DM, Risbridger GP, et al. Inhibin and related peptides. Prog Endocrinol 1988: 13-23.

[77] Mather JP, Moore A, Li RH. Activins, inhibins, and follistatins: further thoughts on a growing family of regulators. Proc Soc Exp Biol Med 1997; 215(3): 209-22.

[78] Woodruff TK. Regulation of cellular and system function by activin. Biochem Pharmacol 1998; 55(7): 953-63.

[79] Massague J. TGF- $\beta$ signal transduction. Annu Rev Biochem 1998; 67: 753-91.

[80] Matzuk MM, Finegold MJ, Mather JP, Krummen L, Lu H, Bradley A. Development of cancer cachexia-like syndrome and adrenal tumors in inhibin-deficient mice. Proc Natl Acad Sci USA 1994; 91(19): 8817-21.

[81] Stenvers KL, Findlay JK. Inhibins: from reproductive hormones to tumor suppressors. Trends Endocrinol Metab 2010; 21(3): 174-80.

[82] Farnworth PG, Harrison CA, Leembruggen P, et al. Inhibin binding sites and proteins in pituitary, gonadal, adrenal and bone cells. Mol Cell Endocrinol 2001; 180(1-2): 63-71.

[83] Harrison CA, Farnworth PG, Chan KL, et al. Identification of specific inhibin A-binding proteins on mouse Leydig (TM3) and sertoli (TM4) cell lines. Endocrinology 2001; 142(4): 1393-402.

[84] Draper LB, Matzuk MM, Roberts VJ, et al. Identification of an inhibin receptor in gonadal tumors from inhibin alpha-subunit knockout mice. J Biol Chem 1998; 273(1): 398-403.

[85] Chong H, Pangas SA, Bernard DJ, et al. Structure and expression of a membrane component of the inhibin receptor system [see comments]. Endocrinology 2000; 141(7): 2600-7.

[86] Lewis KA, Gray PC, Blount AL, et al. Betaglycan binds inhibin and can mediate functional antagonism of activin signaling. Nature 2000; 404(6776): 411-4.

[87] MacConell LA, Leal A, Vale W. The distribution of betaglycan protein and mRNA in rat brain, pituitary and gonads: Implications for a role in inhibin-mediated reproductive functions. Endocrinology 2002; 143(3): 1066-75.

[88] Chapman SC, Woodruff TK. Betaglycan localization in the female rat pituitary: implications for the regulation of follicle-stimulating hormone by inhibin. Endocrinology 2003; 144(12): 5640-9.

[89] Wiater E, Lewis KA, Donaldson C, Vaughan J, Bilezikjian L, Vale W. Endogenous Betaglycan Is Essential for High Potency Inhibin Antagonism in Gonadotropes. Mol Endocrinol 2009; 23(7): 103342.

[90] Escalona RM, Stenvers KL, Farnworth PG, Findlay JK, Ooi GT. Reducing betaglycan expression by RNA interference (RNAi) attenuates inhibin bioactivity in LbetaT2 gonadotropes. Mol Cell Endocrinol 2009; 307(1-2): 149-56.

[91] Wiater E, Harrison CA, Lewis KA, Gray PC, Vale WW. Identification of distinct inhibin and transforming growth factor $\beta$ binding sites on betaglycan: functional separation of betaglycan coreceptor actions. J Biol Chem 2006; 281: 17011-22.

[92] Lopez-Casillas F, Cheifetz S, Doody J, Andres JL, Lane WS, Massague J. Structure and expression of the membrane proteoglycan betaglycan, a component of the TGF-beta receptor system. Cell 1991; 67(4): 785-95.

[93] Farnworth PG, Stanton PG, Wang Y, Escalona R, Findlay JK, Ooi GT. Inhibins differentially antagonize activin and bone morphogenetic protein action in a mouse adrenocortical cell line. Endocrinology 2006; 147(7): 3462-71.

[94] Wiater E, Vale W. Inhibin is an antagonist of bone morphogenetic protein signaling. J Bio Chem 2003; 278(10): 7934-41.

[95] Ethier JF, Farnworth PG, Findlay JK, Ooi GT. Transforming Growth Factor- $\beta$ Modulates Inhibin A Bioactivity in the L $\beta$ T2 Gonadotrope Cell Line by Competing for Binding to Betaglycan. Mol Endocrinol 2002; 16(12): 2754-63.

[96] Looyenga BD, Wiater E, Vale W, Hammer GD. Inhibin-A antagonizes TGFbeta 2 signaling by down-regulating cell surface expression of the TGFbeta coreceptor betaglycan. Mol Endocrinol 2010; 24(3): 608-20.

[97] Farnworth PG, Wang Y, Leembruggen P, et al. Rodent adrenocortical cells display high affinity binding sites and proteins for inhibin $\mathrm{A}$, and express components required for autocrine signalling by activins and bone morphogenetic proteins. J Endocrinol 2006; 188(3): 451-65.

[98] Stenvers KL, Tursky ML, Harder KW, et al. Heart and liver defects and reduced transforming growth factor beta2 sensitivity in transforming growth factor beta type III receptor-deficient embryos. Mol Cell Biol 2003; 23(12): 4371-85.

[99] Roberts VJ, Peto CA, Vale W, Sawchenko PE. Inhibin/activin subunits are costored with FSH and LH in secretory granules of the rat anterior pituitary gland. Neuroendocrinology 1992; 56: 214-24.

[100] Bilezikjian LM, Leal AMO, Blount A, Corrigan AZ, Turnbull AV, Vale W. Rat anterior pituitary folliculo-stellate cells are targets of interleukin-1 $\beta$ and a major source of intrapituitary follistatin. Endocrinology 2003; 144(2): 732-40.

[101] Bilezikjian LM, Vaughan JM, Vale WW. Characterization and the regulation of inhibin/activin subunit proteins of cultured rat anterior pituitary cells. Endocrinology 1993; 133: 2545-53.

[102] Liu ZH, Shintani Y, Wakatsuki M, et al. Regulation of immunoreactive activin-A secretion from cultured rat anterior pituitary cells. Endocr J 1996; 43(1): 39-44.

[103] Carroll RS, Corrigan AZ, Gharib SD, Vale WW, Chin WW. Inhibin, activin and follistatin: regulation of follicle-stimulating hormone messenger ribonucleic acid levels. Mol Endocrinol 1989; 3: $1969-76$

[104] Corrigan AZ, Bilezikjian LM, Carroll RS, et al. Evidence for an autocrine role of activin B within rat anterior pituitary cultures. Endocrinology 1991; 128: 1682-4.

[105] DePaolo LV, Bald LN, Fendly BM. Passive immunoneutralization with a monoclonal antibody reveals a role for endogenous activin$\mathrm{B}$ in mediating FSH hypersecretion during estrus and following ovariectomy of hypophysectomized, pituitary-grafted rats. Endocrinology 1992; 130(3): 1741-3.

[106] Weiss J, Harris PE, Halvorson LM, Crowley JWF, Jameson JL. Dynamic regulation of follicle-stimulating hormone- $\beta$ messenger ribonucleic acid levels by activin and gonadotropin-releasing hormone in perifused rat pituitary cells. Endocrinology 1992; 131(3): 1403-8.

[107] Cameron VA, Nishimura E, Mathews LS, Lewis KA, Sawchenko PE, Vale WW. Hybridization histochemical localization of activin receptor subtypes in rat brain, pituitary, ovary and testis. Endocrinology 1994; 134(2): 799-808.

[108] Wilson ME, Handa RJ. Activin subunit, follistatin, and activin receptor gene expression in the prepubertal female rat pituitary. Biol Reprod 1998; 59(2): 278-83.

[109] Kitaoka M, Kojima I, Ogata E. Activin-A: a modulator of multiple types of anterior pituitary cells. Biochem Biophys Res Commun 1988; 157: 48-54.

[110] Bilezikjian LM, Corrigan AZ, Vale WW. Activin-A modulates growth hormone secretion from cultures of rat anterior pituitary cells. Endocrinology 1990; 126: 2369-76.

[111] Bilezikjian LM, Blount AL, Campen CA, Gonzalez-Manchon C, Vale WW. Activin-A inhibits proopiomelanocortin messenger RNA accumulation and adrenocorticotropin secretion of AtT20 cells. Mol Endocrinol 1991; 5: 1389-95.

[112] Bilezikjian LM, Vale WW. Local extragonadal roles of activins. Trends Endocrinol Metab 1992; 3: 218-23.

[113] Billestrup N, Gonzalez-Manchon C, Potter E, Vale WW. Inhibition of somatotroph growth and $\mathrm{GH}$ biosynthesis by activin in vitro. Mol Endocrinol 1990; 4: 356-62.

[114] Coss D, Thackray VG, Deng CX, Mellon PL. Activin regulates luteinizing hormone beta-subunit gene expression through Smadbinding and homeobox elements. Mol Endocrinol 2005; 19(10): 2610-23.

[115] Woodruff TK, Mather JP. Inhibin, activin and the female reproductive axis. Annu Rev Physiol 1995; 57: 219-44.

[116] Chang H, Brown CW, Matzuk MM. Genetic analysis of the mammalian transforming growth factor-beta superfamily. Endocr Rev 2002; 23(6): 787-823.

[117] Kumar TR, Agno J, Janovick JA, Conn PM, Matzuk MM. Regulation of FSH $\beta$ and GnRH receptor gene expression in activin receptor II knockout male mice. Mol Cell Endocrinol 2003; 212(12): 19-27.

[118] Vassalli A, Matzuk MM, Gardner HAR, Lee KF, Jaenisch R. Activin/Inhibin beta $\mathrm{b}$ subunit gene disruption leads to defects in eyelid development and female reproduction. Gene Dev 1994; 8(4): 414-27. 
[119] Suszko MI, Balkin DM, Chen Y, Woodruff TK. Smad3 mediates activin-induced transcription of follicle-stimulating hormone betasubunit gene. Mol Endocrinol 2005; 19(7): 1849-58.

[120] Pernasetti F, Vasilyev VV, Rosenberg SB, et al. Cell-specific transcriptional regulation of follicle-stimulating hormone-beta by activin and gonadotropin-releasing hormone in the LbetaT2 pituitary gonadotrope cell model. Endocrinology 2001; 142(6): 2284-95.

[121] Thackray VG, Mellon PL, Coss D. Hormones in synergy: regulation of the pituitary gonadotropin genes. Mol Cell Endocrinol 2010; 314(2): 192-203.

[122] Bernard DJ, Fortin J, Wang Y, Lamba P. Mechanisms of FSH synthesis: what we know, what we don't, and why you should care. Fertil Steril 2010; 93(8): 2465-85.

[123] Gregory SJ, Lacza CT, Detz AA, Xu S, Petrillo LA, Kaiser UB. Synergy between activin A and gonadotropin-releasing hormone in transcriptional activation of the rat follicle-stimulating hormonebeta gene. Mol Endocrinol 2005 ; 19(1): 237-54.

[124] Coss D, Hand CM, Yaphockun KK, Ely HA, Mellon PL. p38 mitogen-activated protein kinase is critical for synergistic induction of the FSH(beta) gene by gonadotropin-releasing hormone and activin through augmentation of c-Fos induction and Smad phosphorylation. Mol Endocrinol 2007; 21(12): 3071-86.

[125] Lamba P, Santos MM, Philips DP, Bernard DJ. Acute regulation of murine follicle-stimulating hormone beta subunit transcription by activin A. J Mol Endocrinol 2006; 36(1): 201-20.

[126] Burger LL, Haisenleder DJ, Dalkin AC, Marshall JC. Regulation of gonadotropin subunit gene transcription. J Mol Endocrinol 2004; 33(3): 559-84.

[127] Burger LL, Haisenleder DJ, Wotton GM, Aylor KW, Dalkin AC, Marshall JC. The regulation of FSHbeta transcription by gonadal steroids: testosterone and estradiol modulation of the activin intracellular signaling pathway. Am J Physiol Endocrinol Metab 2007; 293(1): E277-85.

[128] Antenos M, Zhu J, Jetly NM, Woodruff TK. An activin/furin regulatory loop modulates the processing and secretion of inhibin alpha- and betaB-subunit dimers in pituitary gonadotrope cells. J Biol Chem 2008; 283(48): 33059-68.

[129] Bilezikjian LM, Blount A, Leal AMO, Donaldson C, Fischer W, Vale W. Autocrine/paracrine regulation of pituitary function by activin, inhibin and follistatin. Mol Cell Endocrinol 2004; 225: 2936.

[130] Bilezikjian LM, Corrigan AZ, Blount AL, Chen Y, Vale WW. Regulation and actions of Smad7 in the modulation of activin, inhibin and TGF $\beta$ signaling in anterior pituitary cells. Endocrinology 2001; 142(3): 1065-72.

[131] Alexander JM, Bikkal HA, Zervas NT, Laws ER, Jr., Klibanski A. Tumor-specific expression and alternate splicing of messenger ribonucleic acid encoding activin/transforming growth factor-beta receptors in human pituitary adenomas. J Clin Endocrinol Metab 1996; 81(2): 783-90.

[132] Takeda M, Otsuka F, Suzuki J, et al. Involvement of activin/BMP system in development of human pituitary gonadotropinomas and nonfunctioning adenomas. Biochem Biophys Res Commun 2003; 306(4): 812-8.

[133] Uccella S, La Rosa S, Genasetti A, Capella C. Localization of inhibin/activin subunits in normal pituitary and in pituitary adenomas. Pituitary 2000; 3(3): 131-9.

[134] Danila DC, Zhang X, Zhou Y, Haidar JN, Klibanski A. Overexpression of wild-type activin receptor alk4-1 restores activin antiproliferative effects in human pituitary tumor cells. J Clin Endocrinol Metab 2002; 87(10): 4741-6.

[135] Shimonaka M, Inouye S, Shimasaki S, Ling N. Follistatin binds to both activin and inhibin through the common beta-subunit. Endocrinology 1991; 128: 3313-5.

[136] Inouye S, Guo Y, DePaolo L, Shimonaka M, Ling N, Shimasaki S. Recombinant expression of human follistatin with 315 and 288 amino acids: chemical and biological comparison with native porcine follistatin. Endocrinology 1991; 129: 815-22.

[137] Michel U, Farnworth P, Findlay JK. Follistatins: more than folliclestimulating hormone suppressing proteins. Mol Cell Endocrinol 1993; 91: 1-11.

[138] DePaolo LV. Inhibins, activins, and follistatins: the saga continues. Proc Soc Exp Biol Med 1997; 214(4): 328-39.

[139] Phillips DJ, deKretser DM. Follistatin: A multifunctional regulatory protein. Front Neuroendocrinol 1998; 19(4): 287-322.
[140] Welt C, Sidis Y, Keutmann H, Schneyer A. Activins, inhibins, and follistatins: from endocrinology to signaling. A paradigm for the new millennium. Exp Biol Med (Maywood) 2002; 227(9): 724-52.

[141] Fischer WH, Park M, Donaldson C, et al. Residues in the Cterminal region of activin-A determine specificity for follistatin and type II receptor binding. J Endocrinol 2003; 176(1): 61-8.

[142] Keutmann HT, Schneyer AL, Sidis Y. The role of follistatin domains in follistatin biological action. Mol Endocrinol 2004; 18(1): 228-40.

[143] Thompson TB, Lerch TF, Cook RW, Woodruff TK, Jardetzky TS. The structure of the follistatin: activin complex reveals antagonism of both type I and type II receptor binding. Dev Cell 2005; 9(4): 535-43.

[144] Harrington AE, Morris-Triggs SA, Ruotolo BT, Robinson CV, Ohnuma S, Hyvonen M. Structural basis for the inhibition of activin signalling by follistatin. EMBO J 2006; 25(5): 1035-45.

[145] Harrison CA, Chan KL, Robertson DM. Activin-A binds follistatin and type II receptors through overlapping binding sites: generation of mutants with isolated binding activities. Endocrinology 2006; 147(6): 2744-53.

[146] Harrison C, Wiater E, Gray P, Greenwald J, Choe S, Vale W. Modulation of activin and BMP signaling. Mol Cell Endocrinol 2004; 225: 19-24.

[147] DePaolo LV, Bicsak TA, Erickson GF, Shimasaki S, Ling N. Follistatin and activin: a potential intrinsic regulatory system within diverse tissues. Proc Soc Exp Biol Med 1991; 198(1): 500-12.

[148] Balemans W, Van Hul W. Extracellular regulation of BMP signaling in vertebrates: a cocktail of modulators. Dev Biol 2002; 250(2): 231-50.

[149] Canalis E, Economides AN, Gazzerro E. Bone morphogenetic proteins, their antagonists, and the skeleton. Endocr Rev 2003; 24(2): 218-35.

[150] Krneta J, Kroll J, Alves F, et al. Dissociation of angiogenesis and tumorigenesis in follistatin- and activin-expressing tumors. Cancer Res 2006; 66(11): 5686-95.

[151] Ogino H, Yano S, Kakiuchi S, et al. Follistatin suppresses the production of experimental multiple-organ metastasis by small cell lung cancer cells in natural killer cell-depleted SCID mice. Clin Cancer Res 2008; 14(3): 660-7.

[152] Matzuk MM, Lu N, Vogel H, Sellheyer K, Roop DR, Bradley A. Multiple defects and perinatal death in mice deficient in follistatin. Nature 1995; 374(6520): 360-3.

[153] Guo Q, Kumar TR, Woodruff T, Hadsell LA, DeMayo FJ, Matzuk MM. Overexpression of mouse follistatin causes reproductive defects in transgenic mice. Mol Endocrinol 1998; 12(1): 96-106.

[154] Lin SY, Morrison JR, Matzuk MM, de Kretser DM. Spermatogenesis does not require the local production of follistatin. Reproduction 2006; 132(4): 601-5.

[155] Jorgez CJ, Klysik M, Jamin SP, Behringer RR, Matzuk MM. Granulosa cell-specific inactivation of follistatin causes female fertility defects. Mol Endocrinol 2004; 18(4): 953-67.

[156] Shimasaki S, Koga M, Esch F, et al. Porcine follistatin gene structure supports two forms of mature follistatin produced by alternative splicing. Biochem Biophys Res Commun 1988; 152: 717-23.

[157] Michel U, Albiston A, Findlay JK. Rat Follistatin - Gonadal and Extragonadal Expression and Evidence for Alternative Splicing. Biochem Biophys Res Commun 1990; 173(1): 401-7.

[158] Sugino K, Kurosawa N, Nakamura T, et al. Molecular heterogeneity of follistatin, an Activin-Binding protein - higher affinity of the Carboxyl-Terminal truncated forms for heparan sulfate proteoglycans on the ovarian granulosa cell. J Biol Chem 1993; 268(21): 15579-87.

[159] Kimura F, Sidis Y, Bonomi L, Xia Y, Schneyer A. The follistatin288 isoform alone is sufficient for survival but not for normal fertility in mice. Endocrinology 2010; 151(3): 1310-9.

[160] Lin SY, Craythorn RG, O'Connor AE, et al. Female infertility and disrupted angiogenesis are actions of specific follistatin isoforms. Mol Endocrinol 2008; 22(2): 415-29.

[161] Kaiser UB, Lee BL, Carroll RS, Unabia G, Chin WW, Childs GV. Follistatin gene expression in the pituitary: localization in gonadotropes and folliculostellate cells in diestrous rats. Endocrinology 1992; 130: 3048-56.

[162] Lan-Lee B, Unabia G, Childs G. Expression of follistatin mRNA by somatotropes and mammotropes early in the rat estrous cycle. J Histochem Cytochem 1993; 41: 955-60. 
[163] Gospadarowicz D, Lau K. Pituitary follicular cells secrete both vascular endothelial growth factor and follistatin. Biochem Biophys Res Commun 1989; 165: 292-8.

[164] Kogawa K, Nakamura T, Sugino K, Takio K, Titani K, Sugino H. Activin-binding protein is present in pituitary. Endocrinology 1991; 128: $1434-40$.

[165] Farnworth PG, Thean E, Robertson DM, Schwartz J. Ovine anterior pituitary production of follistatin in vitro. Endocrinology 1995; 136(10): 4397-406.

[166] Bilezikjian LM, Corrigan AZ, Vaughan JM, Vale WW. Activin-A regulates follistatin secretion from cultured rat anterior pituitary cells. Endocrinology 1993; 133: 2554-60.

[167] Haisenleder DJ, Aylor KW, Burger LL, Dalkin AC, Marshall JC. Stimulation of FSHbeta transcription by blockade of endogenous pituitary follistatin production: Efficacy of adenoviral-delivered antisense RNA in the rat. Endocrine 2006 ; 29(3): 399-404.

[168] Bauer-Dantoin AC, Weiss J, Jameson JL. Gonadotropin-releasing hormone regulation of pituitary follistatin gene expression during the primary follicle-stimulating hormone surge. Endocrinology 1996; 137(5): 1634-9.

[169] Besecke LM, Guendner MJ, Sluss PA, et al. Pituitary follistatin regulates activin-mediated production of follicle-stimulating hormone during the rat estrous cycle. Endocrinology 1997; 138(7): 2841-8.

[170] Halvorson LM, Weiss J, Bauer-Dantoin AC, Jameson JL. Dynamic regulation of pituitary follistatin messenger ribonucleic acids during the rat estrous cycle. Endocrinology 1994; 134(3): 1247-53.

[171] Prendergast KA, Burger LL, Aylor KW, Haisenleder DJ, Dalkin AC, Marshall JC. Pituitary follistatin gene expression in female rats: evidence that inhibin regulates transcription. Biol Reprod 2004; 70(2): 364-70.

[172] Kaiser UB, Chin WW. Regulation of follistatin messenger ribonucleic acid levels in the rat pituitary. J Clin Invest 1993; 91: 2523-31.

[173] Dalkin AC, Haisenleder DJ, Gilrain JT, Aylor K, Yasin M, Marshall JC. Regulation of pituitary follistatin and inhibin/activin subunit messenger ribonucleic acids (mRNAs) in male and female rats: evidence for inhibin regulation of follistatin mRNA in females. Endocrinology 1998; 139(6): 2818-23.

[174] Bohnsack BL, Szabo M, Kilen SM, Tam DHY, Schwartz NB. Follistatin suppresses steroid-enhanced follicle-stimulating hormone release in vitro in rats. Biol Reprod 2000; 62(3): 636-41.

[175] Leal AMO, Blount AL, Donaldson C, Bilezikjian LM, Vale WW. Regulation of follicle-stimulating hormone secretion by the interactions of activinA, dexamethasone and testosterone in anterior pituitary cell cultures of male rats. Neuroendocrinology 2003; 77(5): 298-304.

[176] Kirk SE, Dalkin AC, Yasin M, Haisenleder DJ, Marshall JC. Gonadotropin-releasing hormone pulse frequency regulates expression of pituitary follistatin messenger ribonucleic acid: a mechanism for differential gonadotrope function. Endocrinology 1994; 135(3): 876-80.

[177] DePaolo LV, Mercado M, Guo Y, Ling N. Increased follistatin (activin-binding protein) gene expression in rat anterior pituitary tissue after ovariectomy may be mediated by pituitary activin. Endocrinology 1993; 132: 2221-8.

[178] Besecke LM, Guendner MJ, Schneyer AL, Bauer-Dantoin AC, Jameson JL, Weiss J. Gonadotropin-releasing hormone regulates follicle-stimulating hormone- $\beta$ gene expression through an activin/follistatin autocrine or paracrine loop. Endocrinology 1996; 137(9): 3667-73.

[179] Kawakami S, Fujii Y, Okada Y, Winters SJ. Paracrine regulation of FSH by follistatin in folliculostellate cell-enriched primate pituitary cell cultures. Endocrinology 2002; 143(6): 2250-8.

[180] Katayama T, Shiota K, Sugino H, Takahashi M. Paracrine effect of folliculo-stellate cells on the growth factor-like action of activin A in anterior pituitary cultures. Endocrinol Jpn 1992; 39(3): 289-97.

[181] Katayama T, Nakashima M, Kyan H, Murakami N, Kuroda H. A role of pituitary adenylate cyclase activating polypeptide (PACAP) as a regulator of paracrine interactions between folliculo-stellate cells and gonadotropes through the control of activin-follistatin interactions. J Vet Med Sci 2000; 62(7): 731-6.

[182] Bilezikjian LM, Corrigan AZ, Blount AL, Vale WW. Pituitary follistatin and inhibin subunit mRNA levels are differentially regulated by local and hormonal factors. Endocrinology 1996; 137(10): 4277-84.
[183] Blount A, Vaughan J, Vale W, Bilezikjian LM. A SMAD-binding element in intron 1 participates in activin-dependent regulation of the follistatin gene. J Biol Chem 2008; 283(11): 7016-26.

[184] Miyanaga K, Shimasaki S. Structural and functional characterization of the rat follistatin (activin-binding protein) gene promoter. Mol Cell Endocrinol 1993; 92: 99-109.

[185] de Groot E, Veltmaat J, Caricasole A, Defize L, van den Eijndenvan Raaij A. Cloning and analysis of the mouse follistatin promoter. Mol Biol Rep 2000; 27(3): 129-39.

[186] Willert J, Epping M, Pollack JR, Brown PO, Nusse R. A transcriptional response to Wnt protein in human embryonic carcinoma cells. BMC Dev Biol 2002; 2(1): 8.

[187] Li H, Malbon CC, Wang HY. Gene profiling of Frizzled-1 and Frizzled-2 signaling: expression of G-protein-coupled receptor chimeras in mouse F9 teratocarcinoma embryonal cells. Mol Pharmacol. 2004; 65(1): 45-55.

[188] Takeda M, Otsuka F, Otani H, et al. Effects of peroxisome proliferator-activated receptor activation on gonadotropin transcription and cell mitosis induced by bone morphogenetic proteins in mouse gonadotrope LbetaT2 cells. J Endocrinol 2007 Jul; 194(1): 87-99.

[189] Kihara S, Yamamoto H, Ohba T, Shimasaki S, Okamura H. Activation of follistatin promoter by $\mathrm{GnRH}$ in LbetaT2 gonadotroph cells. Endocr J 2006; 53(2): 225-35.

[190] Winters SJ, Ghooray D, Fujii Y, Moore JP, Jr., Nevitt JR, Kakar SS. Transcriptional regulation of follistatin expression by GnRH in mouse gonadotroph cell lines: evidence for a role for cAMP signaling. Mol Cell Endocrinol 2007 ; 271(1-2): 45-54.

[191] Mutiara S, Kanasaki H, Oride A, et al. Follistatin gene expression by gonadotropin-releasing hormone: a role for cyclic AMP and mitogen-activated protein kinase signaling pathways in clonal gonadotroph LbetaT2 cells. Mol Cell Endocrinol 2009; 307(1-2): 125-32.

[192] Winters SJ, Dalkin AC, Tsujii T. Evidence that pituitary adenylate cyclase activating polypeptide suppresses follicle-stimulating hormone-beta messenger ribonucleic acid levels by stimulating follistatin gene transcription. Endocrinology 1997; 138(10): 43249.

[193] Blount AL, Schmidt K, Justice NJ, Vale WW, Fischer WH, Bilezikjian LM. Foxl2 and Smad3 coordinately regulate follistatin gene transcription. J Biol Chem 2009; 284: 7631-45.

[194] Bartholin L, Maguer-Satta V, Hayette S, et al. FLRG, an activinbinding protein, is a new target of TGFbeta transcription activation through Smad proteins. Oncogene 2001; 20(39): 5409-19.

[195] Bartholin L, Maguer-Satta V, Hayette S, et al. Transcription activation of FLRG and follistatin by activin A, through Smad proteins, participates in a negative feedback loop to modulate activin A function. Oncogene 2002; 21(14): 2227-35.

[196] Kioussi C, O'Connell S, St-Onge L, et al. Pax6 is essential for establishing ventral-dorsal cell boundaries in pituitary gland development. Proc Natl Acad Sci USA 1999; 96(25): 14378-82.

[197] Treier M, Gleiberman AS, O'Connell SM, et al. Multistep signaling requirements for pituitary organogenesis in vivo. Genes Dev 1998; 12(11): 1691-704.

[198] Ellsworth BS, Egashira N, Haller JL, et al. FOXL2 in the pituitary: molecular, genetic, and developmental analysis. Mol Endocrinol 2006; 20(11): 2796-805.

[199] Ellsworth BS, Burns AT, Escudero KW, Duval DL, Nelson SE, Clay CM. The gonadotropin releasing hormone $(\mathrm{GnRH})$ receptor activating sequence (GRAS) is a composite regulatory element that interacts with multiple classes of transcription factors including Smads, AP-1 and a forkhead DNA binding protein. Mol Cell Endocrinol 2003; 206(1-2): 93-111.

[200] Lamba P, Fortin J, Tran S, Wang Y, Bernard DJ. A novel role for the forkhead transcription factor FOXL2 in activin A-regulated follicle-stimulating hormone beta subunit transcription. Mol Endocrinol. $2009 \mathrm{Jul}$; 23(7): 1001-13.

[201] Corpuz PS, Lindaman LL, Mellon PL, Coss D. FoxL2 Is required for activin induction of the mouse and human follicle-stimulating hormone beta-subunit genes. Mol Endocrinol 2010; 24(5): 103751.

[202] Schmidt D, Ovitt CE, Anlag K, et al. The murine winged-helix transcription factor Foxl2 is required for granulosa cell differentiation and ovary maintenance. Development 2004; 131(4): 933-42. 
[203] Uda M, Ottolenghi C, Crisponi L, et al. Foxl2 disruption causes mouse ovarian failure by pervasive blockage of follicle development. Hum Mol Genet 2004; 13(11): 1171-81.

[204] Uhlenhaut NH, Jakob S, Anlag K, et al. Somatic sex reprogramming of adult ovaries to testes by FOXL2 ablation. Cell 2009; 139(6): 1130-42.

[205] Wijchers PJ, Burbach JP, Smidt MP. In control of biology: of mice, men and Foxes. Biochem J 2006; 397(2): 233-46.

[206] Carlsson P, Mahlapuu M. Forkhead transcription factors: key players in development and metabolism. Dev Biol 2002; 250(1): 123.

[207] Prueitt RL, Zinn AR. A fork in the road to fertility. Nat Genet 2001; 27(2): 132-4.

[208] Cocquet J, Pailhoux E, Jaubert F, et al. Evolution and expression of FOXL2. J Med Genet 2002; 39(12): 916-21.

[209] Crisponi L, Deiana M, Loi A, et al. The putative forkhead transcription factor FOXL2 is mutated in blepharophimosis/ptosis/epicanthus inversus syndrome. Nat Genet 2001; 27(2): 15966.

[210] De Baere E, Dixon MJ, Small KW, et al. Spectrum of FOXL2 gene mutations in blepharophimosis-ptosis-epicanthus inversus (BPES) families demonstrates a genotype--phenotype correlation. Hum Mol Genet 2001; 10(15): 1591-600.

[211] Pannetier M, Fabre S, Batista F, et al. FOXL2 activates P450 aromatase gene transcription: towards a better characterization of the early steps of mammalian ovarian development. J Mol Endocrinol 2006; 36(3): 399-413.

[212] Wang DS, Kobayashi T, Zhou LY, et al. Foxl2 up-regulates aromatase gene transcription in a female-specific manner by binding to the promoter as well as interacting with ad4 binding protein/steroidogenic factor 1. Mol Endocrinol 2007; 21(3): 71225.

[213] Pisarska MD, Bae J, Klein C, Hsueh AJ. Forkhead 12 is expressed in the ovary and represses the promoter activity of the steroidogenic acute regulatory gene. Endocrinology 2004; 145(7): 3424-33.

[214] Shah SP, Kobel M, Senz J, et al. Mutation of FOXL2 in granulosacell tumors of the ovary. N Engl J Med 2009 ; 360(26): 2719-29.

[215] Justice NJ, Blount AL, Schmidt K, Fischer WH, Vale WW, Bilezikjian LM. FoxL2 is required for appropriate expression of follistatin and FSHbeta in anterior pituitary gonadotropes. 91st Annual Meeting of the Endocrine Society 2000; pp 3-244.

(C) Bilezikjian and Vale; Licensee Bentham Open.

This is an open access article licensed under the terms of the Creative Commons Attribution Non-Commercial License (http: //creativecommons.org/licenses/by-nc/3.0/) which permits unrestricted, non-commercial use, distribution and reproduction in any medium, provided the work is properly cited. 